\title{
Vasoactive intestinal polypeptide in the PMSG-primed immature rat ovary and its effect on ovulation in the isolated rat ovary perfused in vitro
}

\author{
G. Schmidt*‡, J. Jörgensen†, P. Kannisto $\ddagger$, F. Liedberg $\ddagger$ B. Ottesen§ and \\ Ch. Owman $\ddagger$ \\ *Department of Obstetrics and Gynecology at County hospital of Helsingborg, Sweden; \\ $\uparrow$ Laboratory of Molecular Endocrinology, Rigshospitalet, University of Copenhagen, Denmark; \\ $\ddagger$ Department of Medical Cell Research, University of Lund, Biskopsgatan 5, S-223 62 Lund, \\ Sweden; and §Department of Obstetrics and Gynecology, Herlev, Denmark
}

\begin{abstract}
Summary. The immature rat ovary contains VIP immunoreactive nerve fibres sparsely distributed around blood vessels, in the interstitial gland and around follicles. The VIP concentration, measured radioimmunologically, decreased significantly after PMSG treatment (10 i.u.), probably due to ovarian enlargement and oedema, while the total VIP content (total of $0.12 \mathrm{pmol}$ in both ovaries) did not change after PMSG priming. The ovulatory effect of VIP was studied using in-vitro perfused ovaries from immature 28-day-old rats primed with 10 i.u. PMSG. In all ovaries perfused, VIP $\left(10^{-7} \mathrm{M}\right)$ induced ovulations with a rate of $2 \cdot 33 \pm 0.56$. The ovulation rate was significantly lower than that of ovaries stimulated by LH $(0.1 \mu \mathrm{g} / \mathrm{ml})(5 \cdot 20 \pm 0.86$ ovulations per ovary). No synergistic effect on the ovulation rate was seen when LH and VIP were administered together $(5 \cdot 20 \pm 0.49$ ovulations per ovary). The results suggest that the neuropeptide VIP may represent one of the local factors involved in the ovulation process.
\end{abstract}

Keywords: VIP; rat ovary; ovulation

\section{Introduction}

Vasoactive intestinal polypeptide (VIP) is a 28 -amino acid peptide located in central and peripheral nerves where it appears to function as a neurotransmitter (Hökfelt et al., 1984; Hansen et al., 1986). VIP-containing nerves innervate many different tissues, thus having a wide variety of actions, including vasodilatation, smooth muscle relaxation in the respiratory, gastrointestinal and urogenital tracts, hormone release from pancreas and facilitatory effects on secretion from salivary glands. The VIP immunoreactive nerve fibres reach the ovary via the suspensory ligament (Dees et al., 1986) and are located around blood vessels, in the interstitial gland and in the follicular wall of the ovary (Kannisto et al., 1986; Ahmed et al., 1986). The existence of VIP mRNA in the rat ovary also suggests a local synthesis of VIP in the gland (Gozes \& Tsafriri, 1986).

The fact that VIP influences smooth muscle cells in the follicular wall (Schmidt et al., 1988a), ovarian steroid production (Fredericks et al., 1983; Davoren \& Hsueh, 1985; Ahmed et al., 1986; Ottesen et al., 1986) and plasminogen activator activity in rat granulosa cells and cumulus-oocyte complexes (Liu et al., 1987) indicates that VIP may be involved in the ovulatory process. VIP immunoreactive fibres have been demonstrated in the hypothalamus and the anterior pituitary and there is reason to believe that VIP is involved in the regulation of prolactin secretion (Kato et al., 1978; Ottesen et al., 1981). To study the direct effect of VIP at the ovarian level, thus avoiding 
systemic effects of the peptide, a well established in-vitro perfusion system for the PMSG-primed immature rat ovary was used (Koos et al., 1984; Schmidt et al., 1986). Immunocytochemical and immunochemical investigation of the immature rat ovary was performed to elucidate any fluctuations in VIP fibre localization and VIP content after the PMSG treatment.

\title{
Materials and Methods
}

\begin{abstract}
Animals. Immature female Sprague-Dawley rats (Anticimex, Stockholm, Sweden) were housed under controlled conditions of $14 \mathrm{~h}$ light $(05: 00-19: 00 \mathrm{~h})$ and $10 \mathrm{~h}$ darkness and fed a standard diet of pellets and water ad libitum. At 26 days of age the rats were primed in the morning by a s.c. injection of 10 i.u. PMSG. On the morning of Day 28 , before the endogenous LH surge which occurs between 15:00 and 18:00 h of that day (Ekholm \& Hillensjö, 1982), the animals were used in different experiments as described below.
\end{abstract}

Immunohistochemistry. Four rats were killed by cervical dislocation at 19:00-20:00 h on Day 28: 2 of the rats had been primed with 10 i.u. PMSG on Day 26, while the other two rats were without PMSG treatment. The ovaries were rapidly removed and placed in a mixture of $2 \%$ paraformaldehyde and $15 \%$ saturated aqueous picric acid solution in $0.1 \mathrm{M}$-phosphate buffer at $\mathrm{pH} 7.2,20^{\circ} \mathrm{C}$ for $24 \mathrm{~h}$. The preparations were repeatedly rinsed in Tyrode's solution containing $10 \%$ sucrose for $48 \mathrm{~h}$. The preparations were then frozen in a cryostat $\left(-20^{\circ} \mathrm{C}\right)$ and sections of $12 \mu \mathrm{m}$ were produced. The sections were placed onto chromalum-coated glass microscope slides for immunostaining. All sections were first incubated in antiserum against VIP (raised in guinea-pig, dilution 1:1280, Milab, Malmö, Sweden, code GP 8701 ) over-night at $+4^{\circ} \mathrm{C}$ according to the indirect immunofluorescence technique of Coons et al. (1955). For visualization of the primary reaction, the sections were then covered with goat anti-guinea-pig IgG (Sigma, St Louis, MO, USA) conjugated to fluorescein isothiocyanate (FITC), dilution $1: 80$, for $45 \mathrm{~min}$ at $+20^{\circ} \mathrm{C}$. The antibodies were diluted in $10 \mathrm{~mm}$-phosphate buffered saline (PBS), pH 7.3, with $0.5 \%$ Triton X-100. The sections were rinsed in PBS between every incubation as well as at the end of the last incubation. The sections were viewed with a Zeiss photomicroscope equipped with a $490 \mathrm{~nm}$ excitation filter to visualize FITC-conjugated antibodies. Control specimens were exposed to antisera that had been preabsorbed with excess amount of antigen (10-100 $\mu \mathrm{g}$ pure VIP per ml diluted antiserum). The slides were examined in a fluorescence microscope fitted with appropriate filter setting for observation of FITC (excitation $490 \mathrm{~nm}$, emission $520 \mathrm{~nm}$ ). No staining was observed in these control specimens.

Chemical determination. PMSG-treated immature rats were killed by cervical dislocation at $08: 00-10: 00 \mathrm{~h}$ and 19:00-20:00 h on Day 28 and at 04:00 $05: 00 \mathrm{~h}$ on Day 29 (7-8 animals were killed at each time). One additional group, consisting of 8 rats which had not received any PMSG injections, were killed at 08:00-10:00 h on Day 28. Both ovaries from each animal were immediately removed, weighed together, frozen on solid $\mathrm{CO}_{2}$ and stored at $-80^{\circ} \mathrm{C}$ until extraction. The extraction procedure used in this study is a modification of the initial method published by Fahrenkrug et al. (1978) for extraction of VIP. The frozen tissue was cut into small pieces on solid $\mathrm{CO}_{2}$ transferred to acid-ethanol at $-20^{\circ} \mathrm{C}$ [final concentration $68 \%(\mathrm{v} / \mathrm{v})$ ethanol with $0.1 \mathrm{M}-\mathrm{HCl}$ ], and incubated overnight at $4^{\circ} \mathrm{C}$. On the next day centrifugation at $10000 \mathrm{~g}$ was performed for $20 \mathrm{~min}$ at $4^{\circ} \mathrm{C}$. The supernatant was stored at $4^{\circ} \mathrm{C}$. The pellet was washed with $1 \mathrm{ml}$ acid-ethanol, and the sample was centrifuged for $10 \mathrm{~min}$ at $4^{\circ} \mathrm{C}$. The first and second supernatants were pooled and neutralized with an aqueous ammonia solution and centrifuged at $3000 \mathrm{~g}$ for $10 \mathrm{~min}$ at $4^{\circ} \mathrm{C}$. Protein in the new supernatant was precipitated by adding 2 volumes of absolute ethanol and 4 volumes of diethyl ether. The precipitate that formed during incubation overnight at $4^{\circ} \mathrm{C}$ was dried by evaporation. The specimens were redissolved in assay buffer and the VIP content was determined according to Fahrenkrug \& Schaffalitzky de Muckadell (1977). The sensitivity of the assay was $3.3 \mathrm{pmol} / 1$; intra- and interassay coefficients of variations were approximately 10 and $15 \%$, respectively. Samples $(1.5 \mathrm{ml})$ from the perfusion medium were withdrawn in some experiments for VIP analysis. The samples were stored at $-18^{\circ} \mathrm{C}$ before radioimmunological determination of VIP as described in detail by Helm et al. (1987). The sensitivity of the assay was $3.8 \mathrm{pmol} / \mathrm{l}$; intra- and interassay variations were $4 \%$ and $8.5 \%$ respectively.

In-vitro perfusion. The surgical procedure and preparation of the ovaries have been described in detail elsewhere (Koos et al., 1984). The rats ( 28 animals) were anaesthetized with pentobarbitone sodium $(40 \mathrm{mg} / \mathrm{kg}$ body wt i.p.; Mebumal: ACO, Solna, Sweden). After injection of $100 \mathrm{IU}$ heparin (Heparin sodium: Kabi Vitrum, Stockholm, Sweden) into a tail vein the abdomen was opened. The abdominal part of the aorta and vena cava were cannulated with infusion catheters (Viggo, Helsingborg, Sweden) and were dissected free together with the right ovary and its ovarian artery and vein. The preparation was then removed and connected to the perfusion apparatus.

The recirculating perfusion system is thoroughly described and has been used in several experiments in our laboratory (Schmidt et al., 1985, 1986, 1988b, c). Three ovaries were perfused simultaneously in three identical perfusion systems. The medum was M 199 with Earle's salts and L-glutamine (Gibco Bio-Cult, Paisley, UK). Bicarbonate $(0.026 \mathrm{M})$ was added to obtain a pH of 7.4 when the medium was continuously oxygenated with a gas mixture of $5 \%$ $\mathrm{CO}_{2}$ and $95 \% \mathrm{O}_{2}$. The medium also contained $75 \mu \mathrm{g}$ benzylpenicillin $\mathrm{G} / \mathrm{ml}, 50 \mu \mathrm{g}$ streptomycin $/ \mathrm{ml}, 0.2 \mathrm{IU}$ heparin/ $\mathrm{ml}, 0.02 \mathrm{IU}$ insulin/ml and $2 \%$ fatty acid-free bovine serum albumin (BSA, Sigma). The perfusion medium was maintained at $37^{\circ} \mathrm{C}$ and the pressure was adjusted to $70-90 \mathrm{mmHg}$, giving a flow of the perfusate of about $0.8 \mathrm{ml} / \mathrm{min}$. 
After $1 \mathrm{~h}$ of perfusion, test substances were added to the perfusate. In experiments with $\mathrm{LH}, 0 \cdot \mathrm{I} \mu \mathrm{g} / \mathrm{ml}$ of the hormone was added to the medium.

VIP (immediate concentration in the system of $10^{-7} \mathrm{M}$ or $10^{-9} \mathrm{M}$ ) was administered after 1 and $8 \mathrm{~h}$ of perfusion. To estimate the concentration of VIP in the perfusate, samples of medium $(1.5 \mathrm{ml})$ were taken $1 \mathrm{~h}$ after the accommodation time and every second hour thereafter. Every sample was replaced with the same amount of fresh medium. The last sample was taken at $06: 00 \mathrm{~h}$ on the following morning, approximately $16-18 \mathrm{~h}$ after the start of perfusion. The ovary was removed from the perfusion system and observed for follicular ruptures with the aid of a Zeiss OPM stereomicroscope at $\times 15-30$ magnification. The medium from the organ chamber was collected and centrifuged $(1600 \mathrm{~g})$ and the pellet examined by phase-contrast microscopy for the presence of oocytes.

Drugs. Ovine luteinizing hormone (NIAKKD-oLH-25) was purchased from NIH, Bethesda, MD, USA. Pregnant mare serum gonadotrophin (PMSG) and vasoactive intestinal polypeptide (VIP) were obtained from Sigma.

Statistics. The number of ovulations per ovary and VIP determinations in ovarian tissue and perfusion medium were expressed as mean values \pm s.e.m. The significance level in the statistical comparison between mean values of the perfused ovaries was calculated according to Student's $t$ test for unpaired observations while mean values from ovarian VIP content were compared with analysis of variance (ANOVA) followed by the Mann-Whitney U-test.

\section{Results}

\section{Presence of VIP on the rat ovary}

The distribution of VIP immunoreactivity is illustrated in Figs 1 and 2. Ovaries from the untreated immature rats contained a sparse number of VIP fibres running in the proximity of blood vessels as well as in the ovarian stroma and around follicles. In ovaries from the PMSG-primed rats excised in the evening of Day 28 (19:00-20:00 h) hardly any VIP fibres were observed.

As shown in Table 1, ovaries from PMSG-primed rats of the same age as controls and killed at 08:00-10:00 $\mathrm{h}$ were more than twice as heavy. The ovarian weight of PMSG-treated rats increased still more in the evening (19:00-20:00 h) and in the following morning (04:00-05:00 h). The VIP concentration (Table 1) was significantly higher in the untreated group when compared with the PMSG-treated groups. The total VIP content in both ovaries (pmol) (Table 1) showed only minor, statistically non-significant, variations between groups.

\section{Ovaries perfused in vitro}

No significant changes in flow rate and perfusion pressure were observed after the addition of any of the substances to the perfusion medium. An oedematous swelling of the ovary was noticed with the stereomicroscope as well as with the naked eye within $3 \mathrm{~h}$ of the LH and VIP administration. No ovulation was seen during the first $9 \mathrm{~h}$ of perfusion. Some of the oocytes recovered in the morning were degenerated.

No ovulations occurred in the control group perfused with saline alone (Table 2, Group 1), whereas all ovaries stimulated by LH and LH + VIP had about the same number of ovulations (Table 2, Group 2 and 3). Administration of VIP after $1 \mathrm{~h}$ and $8 \mathrm{~h}$ of perfusion in a dose corresponding to an immediate concentration in the medium of $10^{-7} \mathrm{M}$ led to a gradual decrease of the peptide in the perfusion medium (Fig. 3). VIP alone (immediate concentration $10^{-7} \mathrm{M}$ ) induced ovulation in all ovaries perfused (Table 2, Group 4) while a very much lower concentration of VIP caused ovulation in 3 out of 6 ovaries (Table 2, Group 5). The ovulation frequency of the two VIP doses tested was, however, significantly lower than that of LH-stimulated ovaries (Table 2, Group 2).

\section{Discussion}

The present study revealed the presence of VIP nerves in close connection with blood vessels, in the interstitial tissue and around ovarian follicles in the untreated rats. The existence and localization 


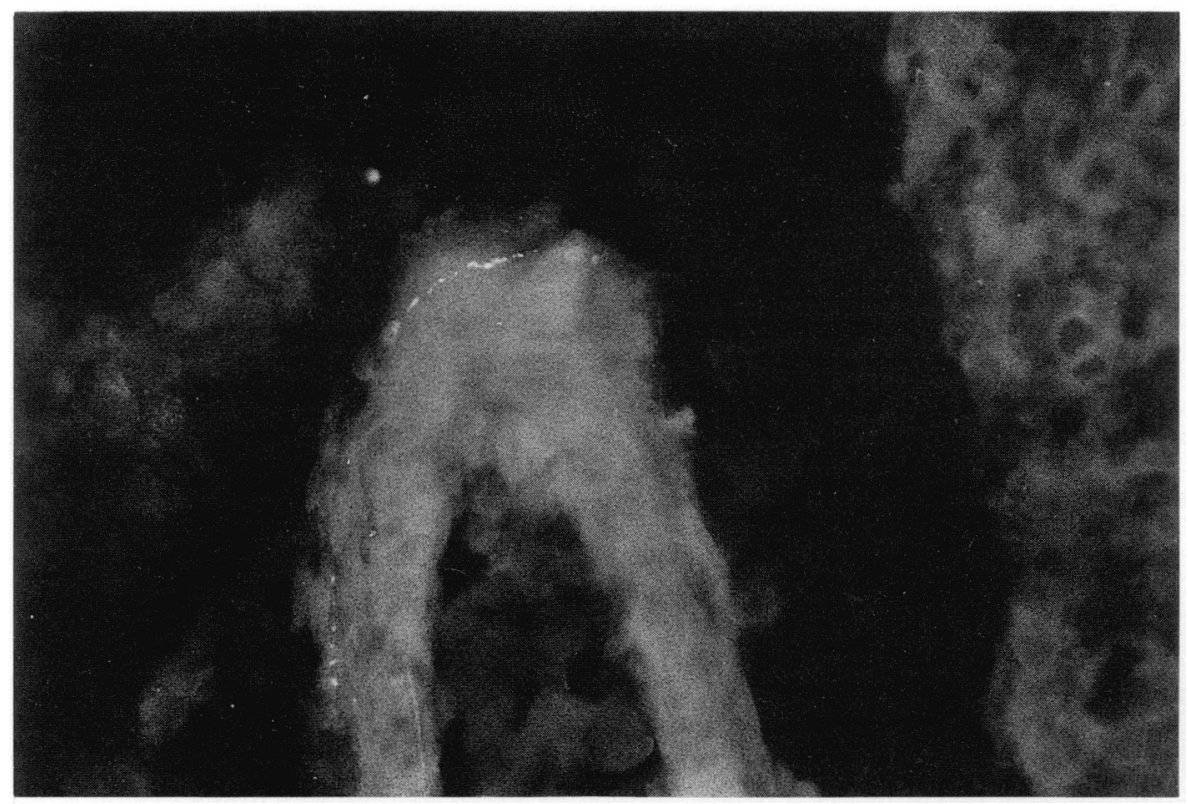

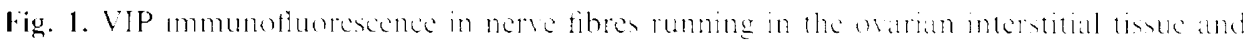

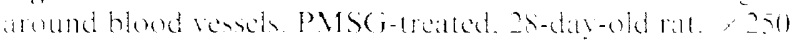

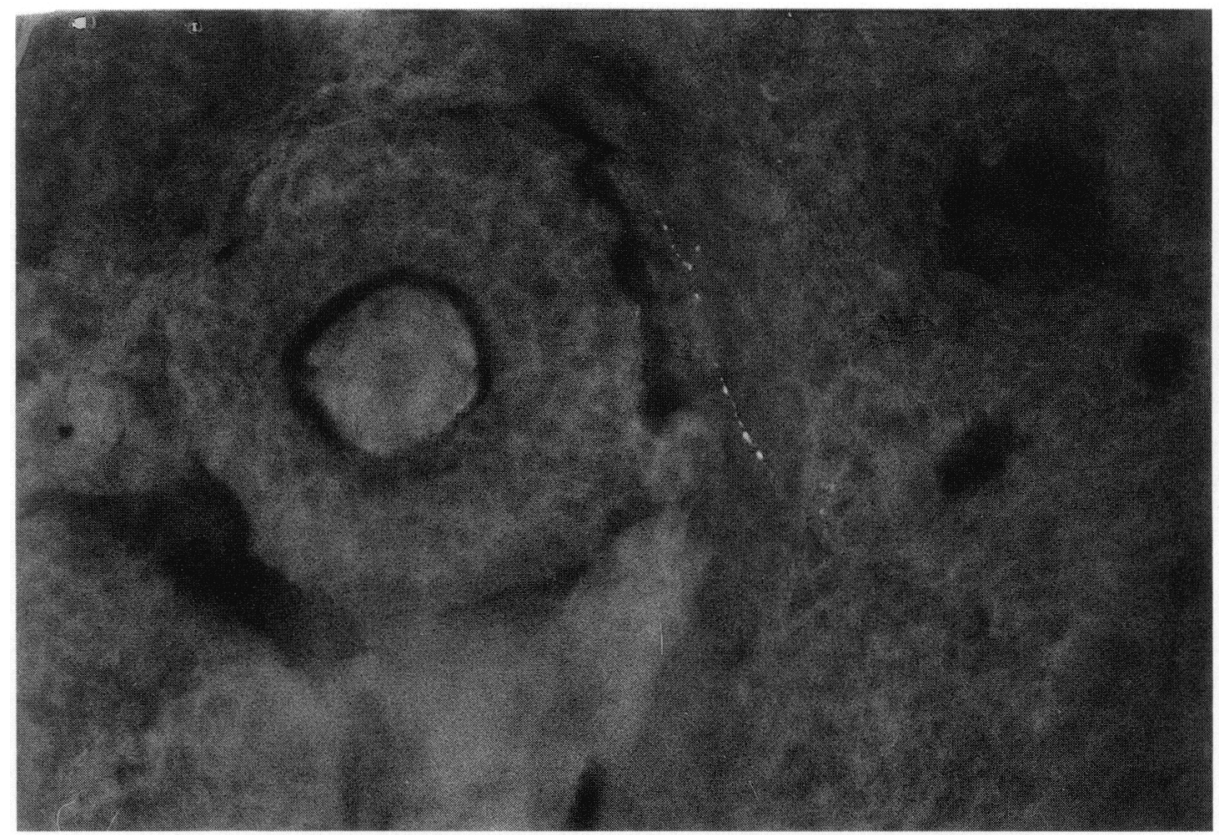

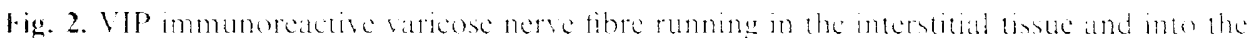

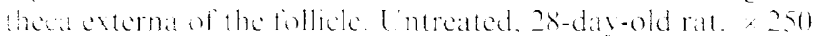


Table 1. Ovarian weight, VIP concentration and total VIP content (both ovaries from each animal pooled) in PMSG-treated animals before $(08: 00-10: 00 \mathrm{~h})$ and after the endogenous LH surge (19:00-20:00 h), and after ovulation (04:00-05:00 h)

\begin{tabular}{|c|c|c|c|c|}
\hline & $\begin{array}{c}\text { Control } \\
(08: 00-10: 00 \mathrm{~h})\end{array}$ & $\begin{array}{c}\text { PMSG } \\
(08: 00-10: 00 \mathrm{~h})\end{array}$ & $\begin{array}{c}\text { PMSG } \\
(19: 00-20: 00 \mathrm{~h})\end{array}$ & $\begin{array}{c}\text { PMSG } \\
(04: 00-05: 00 \mathrm{~h})\end{array}$ \\
\hline No. & 8 & 7 & 8 & 7 \\
\hline $\begin{array}{l}\text { Ovarian weight } \\
\text { (mg wet wt) }\end{array}$ & $17 \cdot 6 \pm 0.8$ & $40 \cdot 3 \pm 1 \cdot 2^{*}$ & $61 \cdot 1 \pm 4 \cdot 5^{*}$ & $74 \cdot 8 \pm 5 \cdot 2^{*}$ \\
\hline $\begin{array}{l}\text { Ovarian VIP conc. } \\
(\mathrm{pmol} / \mathrm{g})\end{array}$ & $7 \cdot 4 \pm 0 \cdot 4^{* *}$ & $3 \cdot 3 \pm 0 \cdot 1$ & $2 \cdot 1 \pm 0 \cdot 1$ & $1 \cdot 7 \pm 0 \cdot 1$ \\
\hline $\begin{array}{l}\text { Total VIP content } \\
\text { (pmol) }\end{array}$ & $0.128 \pm 0.002$ & $0 \cdot 134 \pm 0.004$ & $0 \cdot 126 \pm 0 \cdot 002$ & $0 \cdot 128 \pm 0.003$ \\
\hline
\end{tabular}

Values are mean \pm s.e.m. for 7-8 animals.

${ }^{*} P<0.01,{ }^{* *} P<0.001$ compared with untreated animals (control).

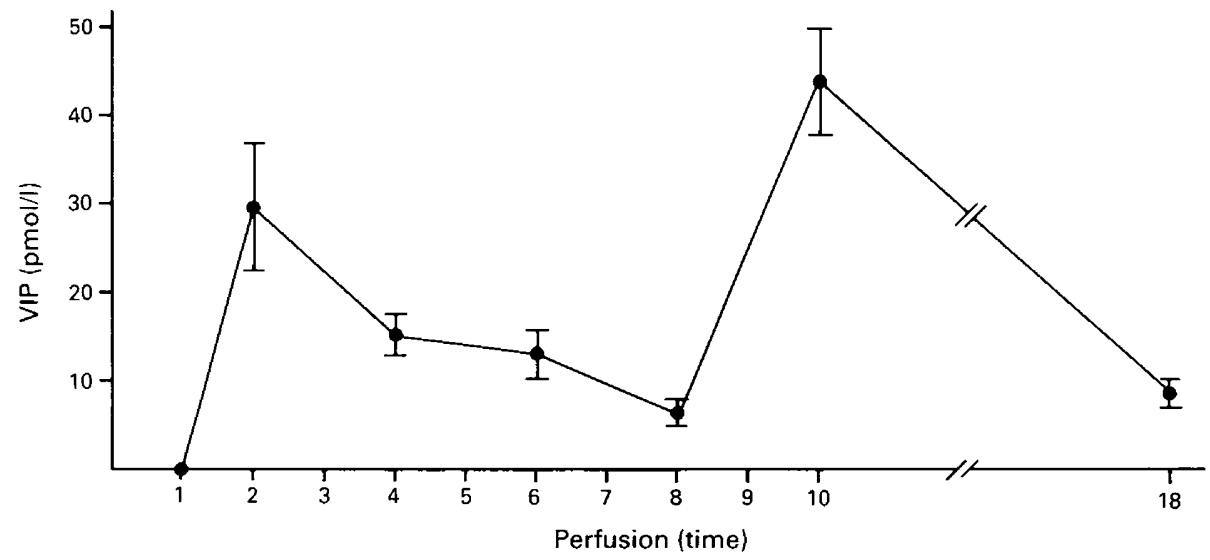

Fig. 3. Concentration of VIP in the medium during in-vitro perfusion of the rat ovary following administration of VIP $\left(10^{-7} \mathrm{M}\right) 1 \mathrm{~h}$ and $8 \mathrm{~h}$ after the start of perfusion. Values are mean \pm s.e.m., $n=5$.

Table 2. Ovulation rates in rat ovaries perfused in vitro in the presence of VIP and/or LH $(0 \cdot 1 \mu \mathrm{g} / \mathrm{ml})$

\begin{tabular}{llcc}
\hline Group & Treatment & $\begin{array}{c}\text { Ovaries ovulating/ } \\
\text { no. perfused }\end{array}$ & $\begin{array}{c}\text { Ovulations } \\
\text { per ovary }\end{array}$ \\
\hline 1 & Control & $0 / 6$ & 0 \\
2 & LH & $5 / 5$ & $5 \cdot 20 \pm 0 \cdot 86$ \\
3 & LH + VIP $\left(10^{-7} \mathrm{M}\right)$ & $5 / 5$ & $5 \cdot 20 \pm 0 \cdot 49$ \\
4 & VIP $\left(10^{-7} \mathrm{M}\right)$ & $6 / 6$ & $2 \cdot 33 \pm 0 \cdot 56^{*}$ \\
5 & VIP $\left(10^{-9} \mathrm{M}\right)$ & $3 / 6$ & $0 \cdot 50 \pm 0 \cdot 22^{* *}$ \\
\hline
\end{tabular}

Values are mean \pm s.e.m., $n=6$ for Groups $1,4 \& 5$ and $n=5$ for Groups $2 \& 3$.

$* P<0.02$ compared with Group 2.

${ }^{* *} P<0.001$ compared with Group 2. 
of VIP fibres in the ovary have been reported by others (Larsson et al., 1977; Håkanson et al., 1982; Kannisto et al., 1986; Ahmed et al., 1986) and indicates that VIP may have an influence on ovarian function. There was a sparse number of VIP fibres in the ovary compared to other organs in the female genital tract (Helm et al., 1981; Ahmed et al., 1986; Kannisto et al., 1986; Owman \& Stjernquist, 1988), and ovarian enlargement after PMSG treatment is probably the reason why no VIP nerves could be discovered in ovaries from the PMSG-primed rats. A depletion of VIP from nerve fibres and ovarian tissue is unlikely since the total ovarian VIP content did not decrease after PMSG treatment. PMSG is able to induce a synchronized development of a first generation of preovulatory follicles with a subsequent endogenous gonadotrophin surge leading to ovulation (Ekholm et al., 1981, 1982). The extraction method used in this study has been evaluated to be at least as effective as the more commonly used 'boiled water-acetic acid' method (Fahrenkrug et al., 1978). Accordingly, the ovarian VIP concentration was of the same magnitude or somewhat higher than reported earlier (Ottesen et al., 1981; Huang et al., 1984; Ahmed et al., 1986) and did not change significantly before and after the LH surge or after ovulation.

Ovaries were perfused with two different concentrations of the neuropeptide: $10^{-9} \mathrm{M}$-VIP corresponds well with basal plasma levels (for references, see Ottesen, 1983), while $10^{-7} \mathrm{M}$-VIP is known to cause certain biological effects in vitro (Ottesen, 1983; Ojeda et al., 1989). All glassware was siliconized and the tubing was made of Teflon, Viton and silicone to reduce adsorption of steroids and other substances during perfusion (for further details see Janson et al., 1982). However, VIP determinations on the perfusion medium showed a decrease in VIP concentration during perfusion, probably due to a certain degree of adsorption and metabolization of the peptide (Ahmed et al., 1986). The VIP dose was therefore repeated after $8 \mathrm{~h}$ of perfusion.

In the present study VIP alone induced ovulation in the in-vitro perfusion system. The ovulatory effect was dose-dependent, the higher dose $\left(10^{-7} \mathrm{M}\right)$ causing approximately $45 \%$ of the ruptures induced by $\mathrm{LH}$. The ovulations were probably due to the presence of the peptide since no follicle ruptures occurred in the perfused control ovaries (see also Koos et al., 1984; Schmidt et al., $1986,1988 \mathrm{~b}, \mathrm{c})$. No synergistic effects on the ovulation rate were seen when $\mathrm{LH}$ was present together with VIP in the perfusion medium. This is in accordance with results from in-vivo experiments with rabbits by Fredericks et al. (1983). Intravenous infusion of VIP in the rabbit during oestrus or ofter ovulation induction with human chorionic gonadotrophin $(\mathrm{hCG})$ increased progesterone secretion, but no effect was seen upon fertility or the number of corpora lutea formed.

There are several ways in which VIP may have a direct ovarian influence on the ovulatory process. Within $3 \mathrm{~h}$ of perfusion, ovaries treated with LH or VIP showed an oedematous swelling while control ovaries maintained approximately their original size. The vascular changes occurring in the ovary and especially in the mature follicles after the LH surge include vasodilatation and increased permeability of the capillaries, leading to extravasation of serum proteins, increasing interstitial oedema and, hence, a greater availability of hormones and other circulating agents to the ovary. The appearance of fenestrations and intercellular gaps between adjacent endothelial cells (Okuda et al., 1983) as ovulation approaches makes a free connection between the capillary lumen and the follicular antrum possible (Bjersing \& Cajander, 1974). These changes and the invasion of leucocytes, basophils and platelets around mature follicles has been compared to an inflammatory reaction (Espey, 1980). Many vasoactive substances such as histamine, 5-hydroxytryptamine and prostaglandins can take part in this event (Espey, 1980; Schmidt et al., 1988b, c). The vasodilatory action of VIP (Said, 1980) and the presence of VIP-containing nerves around arterioles in the ovary, as documented in this study and reported by others (Larsson et al., 1977; Helm et al., 1981; Ahmed et al., 1986), will probably contribute to the preovulatory ovarian hyperaemia. VIP-containing nerves also innervate the theca externa of the follicular wall (Ahmed et al., 1986; Kannisto et al., 1986). The neuromuscular complex of the follicle wall (Burden, 1978; Owman et al., 1979) is suggested as being involved in the ovulatory process (Owman et al., 1979). VIP may influence the follicle wall indirectly by modifying the nerve-mediated effect on the smooth muscle cells in the theca externa (Misbahuddin et al., 1986; Yau et al., 1986) or by a direct relaxant action on the cells (Schmidt et al., 1988a). 
VIP is also known to stimulate ovarian steroid secretion in the rabbit (Fredericks et al., 1983) and rat (Davoren \& Hsueh, 1985; Ahmed et al., 1986), with cAMP as one of the intracellular messengers (Davoren \& Hsueh, 1985; Törnell et al., 1988). Progesterone has been shown to induce ovulation in hypophysectomized rats (Takahashi et al., 1974) as well as in explanted hamster ovaries in vitro (Baranczuk \& Fainstat, 1976), and it facilitates ovulation in incubated rabbit follicles (Testart et al., 1983) and in rabbit ovaries perfused in vitro (Holmes et al., 1985). Forskolin, an activator of adenylate cyclase, is able to induce ovulation in the rabbit ovary perfused in vitro (Holmes et al., 1986), and in the perfused rat ovary both forskolin and cAMP induce ovulation (Brännström et al., 1987). VIP also stimulates plasminogen activator activity in granulosa cells and cumulus-oocyte complexes in the rat (Liu et al., 1987). Since plasminogen activator activity, with generation of proteolytic enzymes, is involved in the ovulatory process (Akazawa et al., 1983; Reich et al., 1985), it is possible that this is yet another way whereby VIP contributes to the process of ovulation.

This work was supported by the Swedish Medical Research Council (No. 14x-732/5680) the Faculty of Medicine, University of Lund, and the Thelma Zoegas Foundation, Helsingborg (Sweden). We thank Ms Mary-Ann Sällström for skilful technical assistance.

\section{References}

Ahmed, C.E., Dees, W.L. \& Ojeda, S.R. (1986) The immature rat ovary is innervated by vasoactive intestinal peptide (VIP)-containing fibers and responds to VIP with steroid secretion. Endocrinology 118, 1682-1689.

Akazawa, K., Matsuo, O., Kosuri, T., Mihara, H. \& Mori, N. (1983) The role of plasminogen activator in ovulation. Acta physiol. Latinoam. 33, 105-110.

Baranczuk, R.J. \& Fainstat, T. (1976) Progesterone induces ovulation of the hamster ovary in vitro. $J$. Endocr. 70, 317-318.

Bjersing, L. \& Cajander, S. (1974) Ovulation and the mechanism of follicle rupture. VI. Ultrastructure of the theca interna and the inner vascular network surrounding rabbit Graafian follicles prior to induced ovulation. Cell Tissue Res. 153, 31-44.

Brännström, M., Koos, R.D., LeMaire, W.J. \& Janson, P.O. (1987) Cyclic adenosine 3',5'-monophosphateinduced ovulation in the perfused rat ovary and its mediation by prostaglandins. Biol. Reprod. 37, 1047 1053.

Burden, H.W. (1978) Ovarian innervation. In The Vertebrate Ovary, pp. 615-638. Ed. R. E. Jones. Plenum Press, New York.

Coons, A.H., Leduc, F.H. \& Connolly, J.M. (1955) Studies on antibody production. A method for the histochemical demonstration of specific antibody and its application to the study of the hyperimmune rabbit. J. exp. Med. 102, 49-60.

Davoren, J.B. \& Hsueh, A.J.W. (1985) Vasoactive intestinal polypeptide: a novel stimulator of steroidogenesis by cultured rat granulosa cells. Biol. Reprod. 33, $37-52$.

Dees, W.L., Ahmed, C.E. \& Ojeda, S.R. (1986) Substance $P$ and vasoactive intestinal polypeptide-containing fibers reach the ovary by independent routes. Endocrinology 119, 638-641.

Ekholm, C. \& Hillensjö, T. (1982) LH-induced inhibition of follicular androgen formation requires intact steroidogenesis. Molec. cell. Endocr. 27, 67-75.
Ekholm, C., Hillensjö, T. \& Isaksson, O. (1981) Gonadotropin releasing hormone agonists stimulate oocyte meiosis and ovulation in hypophysectomized rats. Endocrinology 108, 2022-2024.

Espey, L.L. (1980) Ovulation as an inflammatory reaction-a hypothesis. Biol. Reprod. 22, 73-106.

Fahrenkrug, J. \& Schaffalitzky de Muckadell, O.B. (1977) Radioimmunoassay of vasoactive intestinal polypeptide (VIP) in plasma. J. Lab. Clin. Med. 89, 1379-1388.

Fabrenkrug, J. \& Schaffalitzky de Muckadell, O.B. (1978) Distribution of vasoactive intestinal polypeptide (VIP) in the porcine central nervous system. $J$. Neurochem. 31, 1445-1451.

Fredericks, C.M., Lundquist, L.E., Mathur, R.S., Ashton, S.H. \& Landgrebe, S.C. (1983) Effects of vasoactive intestinal polypeptide upon ovarian steroids, ovum transport and fertility in the rabbit. Biol. Reprod. 28, $1052-1060$.

Gozes, I. \& Tsafriri, A. (1986) Detection of vasoactive intestinal peptide-encoding messenger ribonucleic acid in the rat ovaries. Endocrinology 119, 2606-2610.

Håkanson, R., Sundler, F. \& Uddman, R. (1982) Distribution and topography of peripheral VIP nerve fibres: functional implications. In Vasoactive Intestinal Polypeptide, pp. 121-144. Ed. S. I. Said, Raven Press, New York.

Hansen, B., Ottesen, B., Larsen, J.-J. \& Fahrenkrug, J. (1986) Neurotransmitter-role of VIP in non-adrenergic relaxation of feline myometrium. Peptides 7, 201203.

Helm, G., Ottesen, B., Fahrenkrug, J., Larsen, J.-J., Owman, Ch., Sjöberg, N.-O., Stolberg, B., Sundler, F. \& Walles, B. (1981) Vasoactive intestinal polypeptide (VIP) in the human female reproductive tract: distribution and motor effects. Biol. Reprod. 25, 227-234.

Helm, G., Ekman, R. \& Owman, Ch. (1987) Cyclic fluctuations of vasoactive intestinal polypeptide measured radioimmunologically in various regions of the human fallopian tube. Int. J. Fertil. 32, 467-471. 
Hökfelt, T., Johansson, O. \& Goldstein, M. (1984) Chemical anatomy of the brain. Science, $N Y$ 225, 1326-1334.

Holmes, P.V., Sogn, J., Schillinger, E. \& Janson, P.O. (1985) Effects of high and low preovulatory concentrations of progesterone on ovulation from the isolated perfused rabbit ovary. J. Reprod. Fert. 75, 393-399.

Holmes, P.V., Hedin, L. \& Janson, P.O. (1986) The role of cyclic adenosine $3^{\prime}, 5^{\prime}$-monophosphate in the ovulatory process of the in vitro perfused rabbit ovary. Endocrinology 118, 2195-2202.

Huang, W.M., Gu, J., Blank, M.A., Allen, J.M., Bloom, S.R. \& Polak, J.M. (1984) Peptide-immunoreactive nerves in the mammalian female genital tract. Histochem, J. 16, 1297-1310.

Janson, P.O., LeMaire, W.J., Källfelt, B., Holmes, P.V., Cajander, S., Bjersing, L., Wiqvist, N. \& Ahrén, K. (1982) The study of ovulation in the isolated perfused rabbit ovary. I. Methodology and pattern of steroidogenesis. Biol. Reprod. 26, 456-465.

Kannisto, P., Ekblad, E., Helm, G., Owman, Ch., Sjöberg, N.-O., Stjernquist, M., Sundler, F. \& Walles, B. (1986) Existence and coexistence of peptides in nerves of the mammalian ovary and oviduct demonstrated by immunohistochemistry. Histochemistry 86, 25-34.

Kato, Y., Iwasaki, Y., Iwasaki, J., Abe, H., Yanaihara, N. \& Imura, H. (1978) Prolactin release by vasoactive intestinal polypeptide in rats. Endocrinology 103, $554-558$

Koos, R.D., Jaccarino, F.J., Magaril, R.A. \& LeMaire, W.J (1984) Perfusion of the rat ovary in vitro: methodology, induction of ovulation, and pattern of steroidogenesis. Biol. Reprod. 30, 1135-1141.

Larsson, L.I., Fahrenkrug, J. \& Schaffalitzky de Muckadell, O.B. (1977) Vasoactive intestinal polypeptide occurs in nerves of the female genito-urinary tract. Science, NY 197, 1374-1375.

Liu, Y.-X., Kasson, B.G., Dahl, K.D. \& Hsueh, A.J.W. (1987) Vasoactive intestinal polypeptide stimulates plasminogen activator activity by cultured rat granulosa cells and cumulus-oocyte complexes. Peptides $\mathbf{8}$, $29-33$.

Misbahuddin, M., Houchi, H., Nakanishi, A., Morita, K. \& Oka, M. (1986) Stimulation by vasoactive intestinal polypeptide of muscarinic receptor-mediated catecholamine secretion from isolated guinea pig adrenal medullary cells. Neurosci. Let. 72, 315-319.

Ojeda, S.R., Lara, H. \& Ahmed, C.E. (1989) Potential relevance of vasoactive intestinal peptide to ovarian physiology. Sem. Reprod. Endocr. 7, 52-60.

Okuda, Y., Okamura, H., Kanzaki, H. \& Takenaka, A. (1983) Capillary permeability of rabbit ovarian follicles prior to ovulation. J. Anat. 137, 263-269.

Ottesen, B. (1983) Vasoactive intestinal polypeptide as a neurotransmitter in the female genital tract. $A m$. $J$. Obstet. Gynecol. 147, 208-224.

Ottesen, B., Anderson, A.N., Gerstenberg, T., Ulrichsen, H., Manthorpe, T. \& Fahrenkrug, J. (1981) VIP stimulates prolactin release in women. Lancet 2, 696.
Ottesen, B., Pedersen, B., Nielsen, J. Dalgaard, D. \& Fahrenkrug, J. (1986) Effect of vasoactive intestinal polypeptide (VIP) on steroidogenesis in women. Regulatory Peptides 16, 299-304.

Owman, CH. \& Stjernquist, M. (1988) Origin, distribution, and functional aspects of Aminergic and peptidergic nerves in the male and female reproductive tracts. In Handbook of Chemical Neuroanalomy, Vol. 6, The Peripheral Nervous System, pp. 445-544. Eds A. Björklund, T. Hökfelt \& C. Owman. Elsevier, Amsterdam.

Owman, Ch., Sjöberg, N.-O., Wallach, E.E., Walles, B. \& Wright, K.H. (1979) Neuromuscular mechanisms of ovulation. In Human Ovulation: Mechanisms, Prediction, Detection and Regulation, pp. 57-100. Ed. E. S. E. Hafez. Elsevier, Amsterdam.

Reich, R., Miskin, R. \& Tsafriri, A. (1985) Follicular plasminogen activator: Involvement in ovulation. Endocrinology 116, 516-527.

Said, S.I. (1980) VIP: isolation, distribution, biological actions, structure-function relationship and possible functions. In Gastrointestinal Hormones, pp. 245--273. Ed. G. B. J. Glass. Raven Press, New York.

Schmidt, G., Owman, Ch., Sjöberg, N.-O. \& Walles, B. (1985) Influence of adrenoreceptor agonists and antagonists on ovulation in the rabbit perfused in vitro. J. auton. Pharmac. 5, 24I-250.

Schmidt, G., Owman, Ch. \& Sjöberg, N.-O. (1986) Histamine induces ovulation in the isolated perfused rat ovary. J. Reprod. Fert. 78, 159-166.

Schmidt, G., Kannisto, P. \& Owman, Ch. (1988a) Effects of vasoactive intestinal polypeptide (VIP) and peptide histidine isoleucine (PHI) on isolated ovarian follicle strips. BioSci. Abstr. 1, 183, abstr.

Schmidt, G., Kannisto, P., Owman, Ch. \& Sjöberg, N.-O. (1988b) Is serotonin involved in the ovulatory process of the rat ovary perfused in vitro? Acta physiol. scand. 132, 251-256.

Schmidt, G., Owman, Ch. \& Sjöberg, N.-O. (1988c) Cellular localization of ovarian histamine, its cyclic variations, and histaminergic effects on ovulation in rat ovary perfused in vitro. J. Reprod. Fert. 82, 409-417.

Takahashi, M., Ford, I., Yoshinaga, l. \& Greep, R.O. (1974) Induction of ovulation in hypophysectomized rats by progesterone. Endocrinology 95, 1322-1326.

Testart, J., Thébault, A. \& Lefévre, B. (1983) In-vitro ovulation of rabbit ovarian follicles isolated after the endogenous gonadotrophin surge. J. Reprod. Fert. 68, $413-418$.

Törnell, J., Carlsson, B. \& Hillensjö, T. (1988) Vasoactive intestinal polypeptide stimulates oocyte maturation, steroidogenesis, and cyclic adenosine $3^{\prime}, 5^{\prime}$-monophosphate production in isolation preovulatory rat follicles. Biol. Reprod. 39, 213-220.

Yau, W.M., Dorsett, J.A. \& Youther, M.L. (1986) Calcium-dependent stimulation of acetylcholine release by substance $\mathbf{P}$ and vasoactive intestinal polypeptide. Eur. J. Pharmacol. 120, 241-243.

Received 9 February 1990 